\title{
Analysis of Ash Content in Composite Biomass Fuels
}

\author{
Edgars Čubars ${ }^{1}$, Liena Poiša ${ }^{2}$. \\ ${ }^{1}$ Rezekne Academy of technologies, Geo technology and Eco industry Research center, \\ Atbrīvošanas aleja 115/k-4, LV 4601, email: edgars.cubars@inbox.lv; ${ }^{2}$ email: lienapoisa@inbox.lv
}

\begin{abstract}
The study reveals research of ash content in different composite biomass fuels. It contains analysis of samples obtained from various local Latvian biomass types, i.e. reed, wood, hemp, flax shives and peat, by combining them in different proportions. Ash is a by-product derived from combustion process consisting mostly of inorganic substances that are left after a fuel is burnt. High level of ash content in a fuel is undesirable because it causes problems in automation of biomass combustion process. Previous studies carried out by the author show that average ash content in reeds is $2 \%$, which is a high index comparing with wood where ash content is approximately 0,5-1\%. Thus, the high ash content in reeds my cause problems in reed combustion in solid fuel boilers. Besides, it is not possible to ensure permanent reed collection that would ensure continuous reed fuel generating process all year long. In order to reduce the ash content to the optimal level and to diversify raw materials necessary for biomass fuel generating process, the author suggests using composite fuels by combining different biomass types. The study contains optimal combining proportions of different biomass types for composite fuel production basing on the ash content in them.
\end{abstract}

Keywords: ash content in fuels, common reed, wood, peat, hemp, flax shives, composite fuels.

\section{INTRODUCTION}

One of the most popular renewable energy sources (RES) is biomass. Use of the biomass takes a considerable part in energy industry, mainly due to the use of timber that is one of the main natural resources in Latvia. However, recently an increased attention has been paid to the use of cultivable energy plants and water plants.

The use of such non-traditional sources is disrupted by the fact that in Latvia there is no any thorough assessment of the amount of RES, potential and long-term availability of each energy source in the respective regions. For a rational and appropriate long-term use of RES, the available amount and quality parameters of the respective RES should be assessed [1]. Thus far, the potential of water plant biomass in Latvia as an energy resource has not been taken into account. There is also insufficient interest in peat and various cultivable energy plants. Given Latvian conditions, reeds (Phragmites australis (Cav.) Trin. Ex Steud.) growing in natural or artificial water bodies could be used for energy generation $[2,3,4]$. Researches conducted by foreign scientists also indicate that reeds can be used as a raw material for fuel generation. [5,6]. Overall, reeds from more than 2000 lakes located in Latvia may be used for energy generation. [7] Use of reeds, compared with cultivable energy plants, has its advantages and disadvantages. The main advantage is the fact that it is not necessary to occupy areas of agricultural lands and that no expenses are needed for settlement of plantations. The main disadvantage is the fact that no subsidies are paid for cultivation of these plants, or for energy plants; besides, it is relatively complicated to gather such plants mechanically and a special equipment is needed.

Flax processing residues, i.e. shives, straw, hemp fibres, peat, hay, as well as other energy plants can also be used. The main problem related to their use is the fact that these resources are available seasonally; besides, their thermal qualities are often worse if compared to timber. Therefore, it can be suggested to use composite fuels where timber is used as a base, while other energy plants are added as supplementary fuels, e.g. in pellet production. Thus, when resources are provided irregularly, they could be easily replaced by other types of biomass.

One of the most important fuel characteristics is ash content. Ash is a by-product of fuel combustion mainly consisting of inorganic substances obtained after fuel combustion. High ash content is a negative feature because it makes the automation of biomass combustion process more difficult [8].

The paper studies the ash content in fuels, depending on the amount of fuel added to wood. Ash content in fuels was assessed according to the Standard ISO 17225-1: 2014 Solid biofuels. Fuel specifications and classes. Part 1: General requirements [9]. According to this standard, the quality of composite fuel was evaluated basing on ash content.

Basic material for the research consisted of industrially produced wood pellets, which can be purchased in trading venues in Latvia; various types http://dx.doi.org/ 10.17770/etr2017vol3.2524 
of local biomass, i.e. reeds, flax shives, peat, hemp fibre, hay, as well as fossil fuel, i.e. coal dust, were added.

\section{MATERIALS AND METHODS}

The study used industrially produced wood pellets ground into powder using a mill. Various types of local biomass available in Latgale region were added to the wood chips, i.e. reeds, flax shives, peat, hay, hemp fibre, as well as coal dust, that had previously been dried and ground into powder. In order to determine the ash content dependence on the amount of various types of biomass added to the wood, respective samples were prepared and analysed in the following proportions. Sample 1: 100\% wood; Sample 2: $90 \%$ of wood and $10 \%$ of other fuels; Sample 3: $80 \%$ of wood and $20 \%$ of other fuels, Sample 4: $60 \%$ of wood and $40 \%$ of other fuels; Sample 5: $40 \%$ of wood and $60 \%$ of other fuels; Sample 6: $20 \%$ of wood and $80 \%$ of other fuels; Sample $100 \%$ other fuels. Ash content in the samples was determined using the standard method CEN/TS 14775:2004 [10]. The samples were dried at the temperature of $105^{\circ} \mathrm{C}$. They were later placed into crucibles and weighted (Fig. 1).

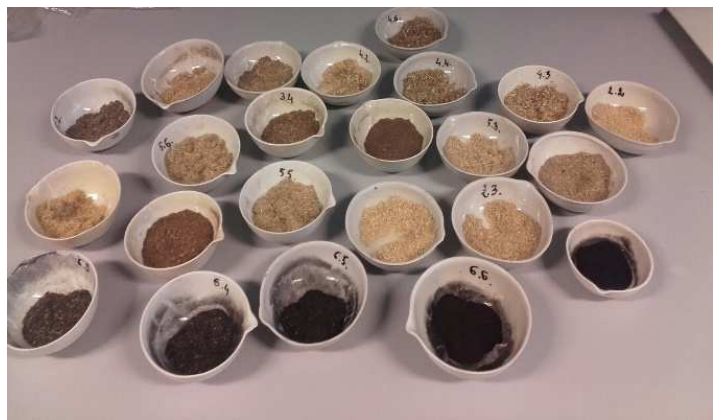

Fig. 1. Samples analysed to determine the ash content

For combustion of samples the furnace "Nabertherm" was used (Fig. 2).

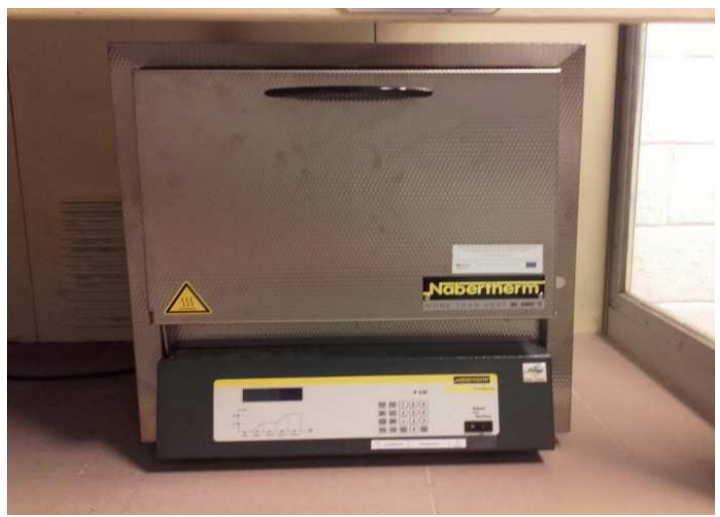

Fig. 2. The furnace used to determine the ash content

After combustion in the furnace at the temperature of $550^{\circ} \mathrm{C}$ the crucibles with ash (Fig. 3) were taken out, cooled and weighted, the respective calculations of ash content were also performed. Each sample was analysed trice, measurement error assessment was also carried out [10].

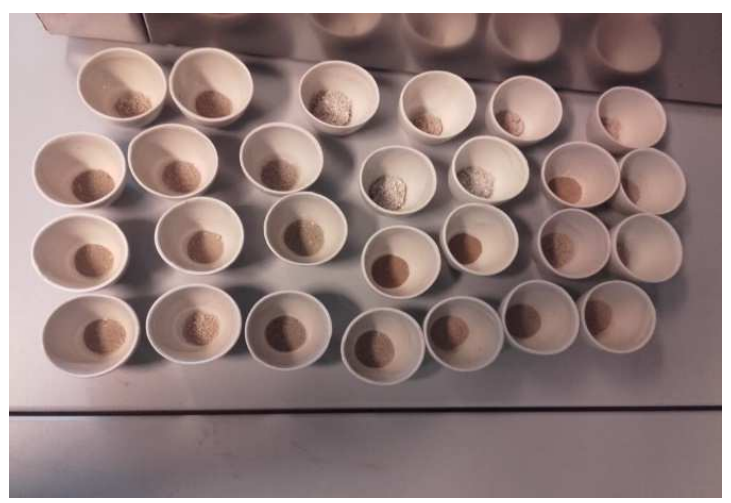

Fig. 3. Samples after combustion

\section{RESULTS AND DISCUSSION}

According to the Standard ISO 17225-1: 2014 Solid biofuels. Fuel specifications and classes. Part 1: General requirements (see the Standard below), fuels, basing on the ash content, are divided into ten classes. See Table 1.

Table 1

Classes of solid biofuels basing on ash content

\begin{tabular}{|c|c|c|c|c|c|c|c|c|c|c|}
\hline Class & $\begin{array}{c}\mathrm{A} \\
0.5\end{array}$ & $\begin{array}{c}\text { A } \\
0.7\end{array}$ & $\begin{array}{c}\text { A } \\
1.0\end{array}$ & $\begin{array}{c}\mathrm{A} \\
1.5\end{array}$ & $\begin{array}{c}\mathrm{A} \\
2.0\end{array}$ & $\begin{array}{c}\text { A } \\
3.0\end{array}$ & $\begin{array}{c}\mathrm{A} \\
5.0\end{array}$ & $\begin{array}{c}\text { A } \\
7.0\end{array}$ & $\begin{array}{c}\mathrm{A} \\
10 . \\
0\end{array}$ & $\mathrm{~A} 10.0+$ \\
\hline $\begin{array}{c}\text { Ash } \\
\text { content, } \\
\%\end{array}$ & $\begin{array}{c}\leq \\
0,5 \\
\%\end{array}$ & $\begin{array}{c}\leq \\
0,7 \\
\%\end{array}$ & $\begin{array}{c}\leq \\
1,0 \\
\%\end{array}$ & $\begin{array}{c}\leq \\
1,5 \\
\%\end{array}$ & $\begin{array}{c}\leq \\
2,0 \\
\%\end{array}$ & $\begin{array}{c}\leq \\
3,0 \\
\%\end{array}$ & $\begin{array}{c}\leq \\
5,0 \\
\%\end{array}$ & $\begin{array}{c}\leq \\
7,0 \\
\%\end{array}$ & $\begin{array}{l}\leq \\
10 \\
\%\end{array}$ & $\begin{array}{c}>10 \% \\
\text { (maximum } \\
\text { value to be } \\
\text { stated) }\end{array}$ \\
\hline
\end{tabular}

Ash content in timber without bark is around $0.3 \%$, it is higher in the bark and amounts to $4-5 \%$ [12.9] Ash content in wood pellets analysed in our study amounted to $0.43 \pm 0.01 \%$, which is a good indicator. Pellets, basing on the ash content, correspond to the highest class A 0.5. Ash content grows when reed biomass is added to the wood (Figure 3). Ash content in $100 \%$ reed biomass amounted to $2.39 \pm 0.11 \%$, which corresponds to the class A 3.0. In another study, ash content in reeds was also similar, i.e. $2.76 \%$ [13]. Thus, it can be concluded that adding reed biomass to the wood increases ash content and deteriorates fuel quality.

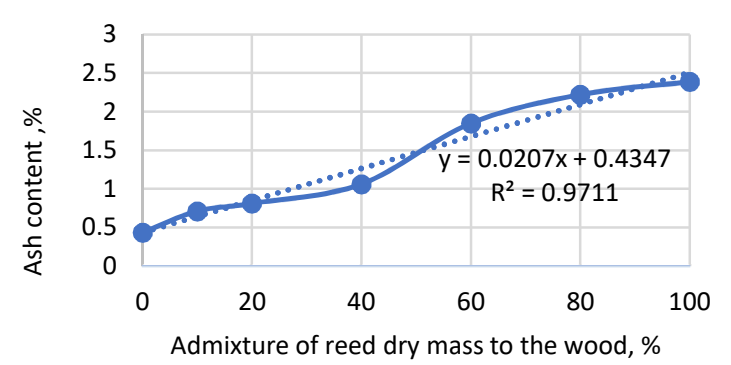

Fig. 3. Ash content in the wood-reed composite fuel 
In order to determine the proportions of wood and reeds in the composite fuel to meet certain quality standards, the following equation (Equation 1) was used:

$$
\mathrm{A}=0,0207 \mathrm{R}+0,4347
$$

Where, A- Ash content in composite wood-reed fuel, \%

R-admixture of reed dry mass to the wood \%

This equation can be used to find critical ash content values for each class. In the class A 0.5 reed admixture to the wood may amount to $3.2 \%$, in the class A 0.7 it may range from $3.3 \%$ to $12.8 \%$, in the class A 1.0 reed admixture may amount to 12.9 $27.3 \%$, in the class A 1.5 from $27.4 \%$ to $51.5 \%$, in the class A 2.0 from $51.6 \%$ to $75.6 \%$, while reed admixture exceeding $75.6 \%$, basing on the reed content, corresponds to the class A 3.0.

Thus, $3.2 \%$ of reed biomass may be added to wood pellets without decreasing fuel quality in terms of ash content. If such a high quality is not necessary, the amount of reed biomass admixture may be increased in accordance with the above-mentioned ranges.

Adding flax shives to the wood increased rapidly the ash content (Figure 4). Ash content in the biomass of pure flax shives was high, it amounted to $17.76 \pm$ $1.05 \%$, which ranks flax shives into the class A $10+$. Other researchers have also found such a high ash content in rice straw, i.e. about $1-20 \%$ [14] Adding flax shives to the wood increases rapidly ash content and deteriorates fuel quality. Using flax shives in production of biomass fuel might be difficult and uneconomical because of the high ash content.

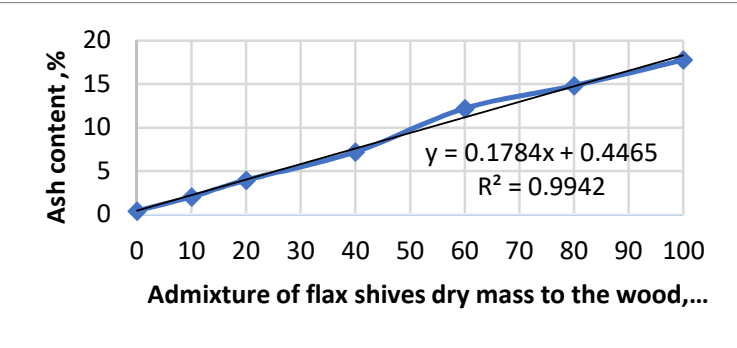

Fig. 4. Ash content in the wood-flax shives composite fuel

In order to determine the proportions of wood and flax shives in the composite fuel to meet certain quality standards, the following equation (Equation 2) was used:

$$
A=0,1784 R+0,4465
$$

Where, A- Ash content in composite wood-flax shives fuel, \%; R- admixture of flax shives dry mass to the wood, $\%$.

This equation can be used to find critical ash content values for each class. In the class A 0.5 admixture of flax shives dry mass to the wood may not exceed $0.3 \%$. In the class A 0.7 admixture of flax shives may amount to $0.3-1.4 \%$, in the class A 1.0 admixture of flax shives may amount to $1.5-3.1 \%$, in the class A 1.5 it may amount to $3.2 \%-5.9 \%$, in the class A 2.0 it may amount to $6 \%-8,7 \%$, in the class A 3.0 it may amount to $8,8 \%-14,3 \%$, in the class A 5.0 it may amount to $14.4-25.5 \%$, in the class A 7.0 it may amount to $25.6 \%-36.7 \%$, in the class A 10.0 it may amount to $36.8-53.6 \%$, while flax shive-wood composite fuel where content of flax shives exceeds $53.6 \%$ corresponds to the class A 10+. Therefore, flax shives form a biomass with a high ash content, growth in the proportion of this material increases rapidly the ash content in the composite fuel. Ash content in flax shives is almost eight times higher than the ash content in reeds and forty times higher than in wood. The high ash content can cause problems in automation of combustion process. Adding peat to the wood increases the ash content (Figure 5). In our research, ash content in the biomass of pure peat amounted to $4.13 \pm 0.21 \%$, which ranks peat, basing on the ash content, into the class A 5.0. Adding peat to the wood increases ash content.

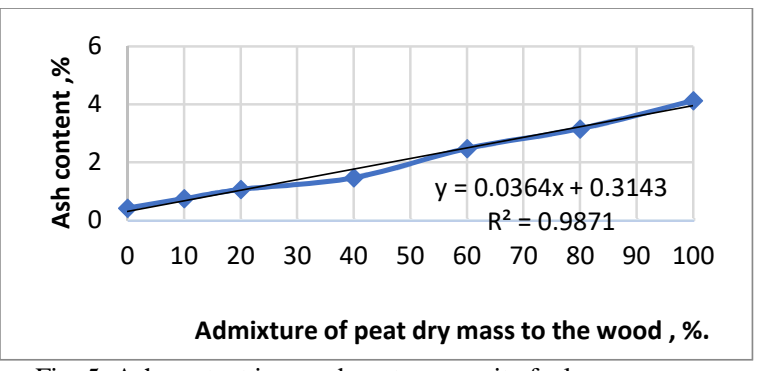

Fig. 5. Ash content in wood-peat composite fuel

In order to determine the proportions of wood and peat in the composite fuel to meet certain quality standards, the following equation (Equation 3) was used:

$$
A=0,0364 R+0,3143
$$

Where, A- Ash content in composite wood-peat fuel, $\%$

R-Admixture of peat dry mass to the wood, $\%$.

This equation can be used to find critical ash content values for each class. In the class A 0.5 admixture of peat to the wood may not exceed $5.1 \%$. In the class A 0.7 admixture of peat may amount to $5.2-10.6 \%$, in the class A 1.0 admixture of peat may amount to $10.7-18.8 \%$, in the class A 1.5 it may amount to $18.9-32.6 \%$, in the class A 2.0 it may amount to $32.7-46.3 \%$, in the class A 3.0 it may amount to $46.4-73.8 \%$. Admixture of peat to the wood chips exceeding $73.9 \%$ corresponds to the class A 5.0.

In 2016, in order to receive area payments for tidying up permanent grasslands, the grass had to be mowed and removed from the field. Thus, the farms without livestock faced the problem of hay 
overproduction, which could be solved by using hay as additional fuel. Ash content in canary seed may range from 2.5 to $10 \%$. [9] Overall ash content in dry grass is about 7\% [12]. Festulolium, timothy, and meadow fescue also have high ash content, i.e. 6-8\%. [15] In our research, ash content in pure straw amounted to $7.73 \pm 0.01 \%$, which ranks pure straw, basing on the ash content, into the class A 10.0. Adding straw to the wood increased ash content in the fuel (Figure 6).

In order to determine the proportions of wood and straw in the composite fuel to meet certain quality standards, the following equation (Equation 4) was used:

$$
A=0,0728 R+0,2346
$$

Where, A- Ash content in composite wood-straw fuel, $\%$

$\mathrm{R}$ - admixture of straw dry matter to the wood, $\%$.

This equation can be used to find critical ash content values for each class.

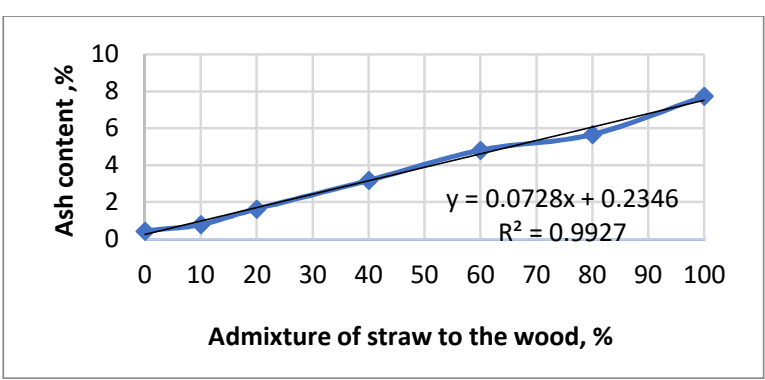

Fig. 6. Ash content in wood-straw composite fuel

In class A 0.5 maximum amount of straw admixture to the wood may be $3.6 \%$. In class A 0.7 straw admixture may amount to $3.7-6,3 \%$, in class A 1.0 it may amount to $6.4-10.5 \%$, in class A 1.5 it may amount to $10.6-17.4 \%$, in class A 2.0 it may amount to $17.5-24.2 \%$, in class A 3.0 it may amount to $24.3-38 \%$, in class A 5.0 it may amount to 38.1 $65.4 \%$, in class A 7.0 it may amount to $65.5-93 \%$. If straw admixture to the wood exceeds 93\%, it corresponds to the class A 10. One of the most promising energy plants for cultivation is hemp. Ash content in hemp varies in different studies: it may be $2 \%$ [16] or around 3\% [13]. In addition, it may also vary for different parts of the plant, such as leaves, stems, etc., as it was revealed before in the study of corn plants, where ash content in leaves was 2 times higher than in its trunk [17]. Furthermore, the ash content in plants depends on the time of harvesting, it is recommended to harvest the cultivated energy plants as late as possible in the autumn [18]. In our study, ash content in hemp fibres was higher and amounted to $3.78 \pm 0.09 \%$, which ranks pure hemp fibre into the class A 5.0, basing on it ash content. Adding hemp fibre to the wood increased ash content in the fuel (Figure 7).
Figure 7. Ash content in wood-hemp fibre composite fuel.

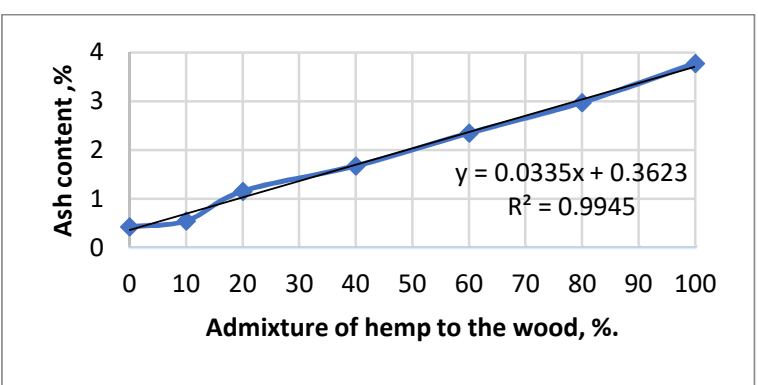

Fig. 7. Ash content in wood-hemp fibre composite fuel.

In order to determine the proportions of wood and hemp fibre in the composite fuel to meet certain quality standards, the following equation (Equation 5) was used:

$$
\mathrm{A}=0,0335 \mathrm{R}+0,3623
$$

Where, A-Ash content in composite wood-hemp fuel, $\%$

R-Admixture of hemp fibre dry mass, $\%$.

This equation can be used to find critical ash content values for each class. In class A 0.5 maximum amount of hemp fibre admixture to the wood may be $4.1 \%$. In class A 0.7 admixture of hemp fibre may amount to $4.2-10.0 \%$, in class A 1.0 it may amount to $10.1-19.0 \%$, in class A 1.5 it may amount to $19.1-34 \%$, in class A 2.0 it may amount to 34.1$48.9 \%$, in class A 3.0 it may amount to $49-78.8 \%$. If the amount of hemp fibre admixture exceeds $78.9 \%$, it corresponds to the class A 5.0. Wood may be also mixed with various fossil fuels, which would increase its energy value. Coal dust may be used as one of the components in composite fuels. Ash content in coal available in Latvian markets was established. Ash content in pure coal dust was high, it amounted to $8.27 \pm 0.39 \%$, which ranks it into class A 10.0. Adding coal dust to the wood increases ash content in the fuel (Figure 8).

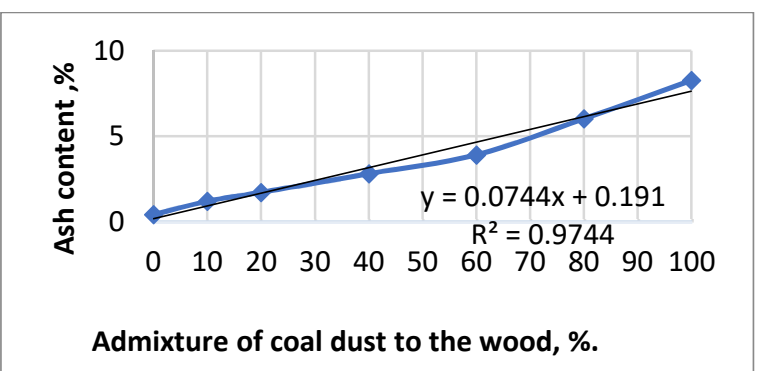

Fig. 8. Ash content in wood-coal dust composite fuel.

In order to determine the proportions of wood and coal dust in the composite fuel to meet certain quality standards, the following equation (Equation 6) was used: 


$$
\mathrm{A}=0,0744 \mathrm{R}+0,191
$$

Where, A-Ash content in composite wood-coal fuel, $\%$

R-Admixture of coal dust to the wood, $\%$.

This equation can be used to find critical ash content values for each class.

In class A 0.5 maximum amount of coal dust admixture to the wood may be $4.1 \%$. In class A 0.7 admixture of coal dust may amount to $4.2-6.8 \%$, in class A 1.0 it may amount to $6.9-10.9 \%$, in class A 1.5 it may amount to $11-17.6 \%$, in class A 2.0 it may amount to $17.7-24.3 \%$, in class A 3.0 it may amount to $24.4-37.8 \%$, in class A 5.0 it may amount to $37.9-64.6 \%$, in class A 7.0 it may amount to 64.7 $91.5 \%$. If the amount of coal dust admixture to the wood exceeds $91.5 \%$, it corresponds to the class A 10.0.

High ash content is a negative feature in fuels, because it makes the automation of combustion process more difficult. Combustion of fuel with a high ash content involves additional expenses related to ash disposal and maintenance of combustion equipment. It has been concluded that mixing wood and other biofuels or fossil fuels inevitably increases the ash content therein (Figure 9).

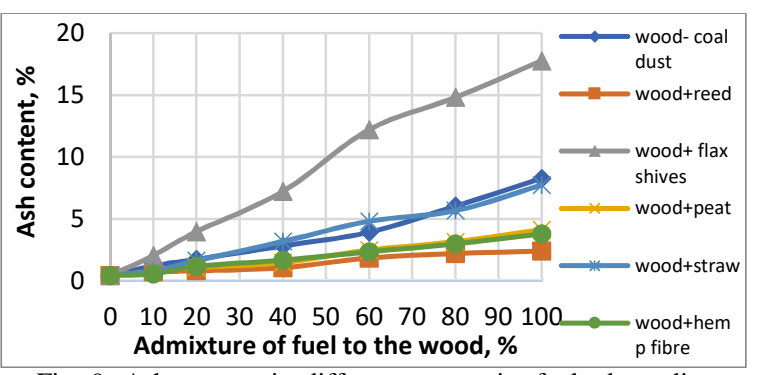

Fig. 9. Ash content in different composite fuels depending on the amount of fuel added to the wood

As we can see from the Figure 9, analysis of ash content in fuels revealed that the best results (lowest ash content) was in the wood-reed composite fuel; ash content in the fuel containing admixture of peat and hemp was also relatively low. The study results indicate that the wood, in order to keep ash content of the class A 0.5 , can be mixed with a relatively small amount of these fuels, i.e. 3-5\%. If the final product is intended for use in furnaces, which allows for a higher ash content, the added amount of biomass can be increased according to the estimates above. To keep the ash amount corresponding to class A 1.0, the wood may be mixed with $27 \%$ of reed, $18 \%$ of peat and $19 \%$ of hemp. The second group, basing on the results of the study, contains wood-straw composite fuel and wood-coal dust composite fuel. In order to correspond to the class A 0.5 , wood can be mixed with about 3 or $4 \%$ of these fuels. For the ash content in class A $0.5,10 \%$ of straw and coal dust may be added. Use of such composite fuels is possible, but the increased amount of ash should be considered.
Given that the heat of combustion of coal dust is higher than that of the wood, such a combination could improve the overall fuel quality. In addition, changes in the heat of combustion should be examined in the future.

The highest ash content was found in flax shives, it exceeds the characteristics of wood by approximately 40 times. Consequently, the use of flax shives in composite fuels is not recommended.

\section{CONCLUSION}

Wood is a fuel with a low ash content, and admixture of various biomass types available in Latvia, as well as admixture of coal dust to the wood in composite duels, increases ash content in the respective fuels.

The lowest ash content was found in reeds, peat and hemp fibre, therefore these types of biofuels are the most appropriate to be added to wood in composite fuels.

Basing on experimental studies, equations have been created for calculation of amounts of fuels to be added to the wood.

The studied wood pellets, looking at the ash content, correspond to the highest class A 0.5. In order to keep ash content within the limits of class A 0.5 , it is possible to add $3-4 \%$ of reeds, peat, hemp fibre, coal or straw. Ash content in flax shives ash content is forty times higher than ash content in wood, therefore the use of flax shives in composite fuels rapidly increases the overall ash content and is not recommended.

\section{REFERENCES}

[1] Noviks G., Zorins A. (2011) National recomendation report. In: Joint European-Latin American Universities Renewable energy Project, Rēzeknes Augstskola Rēzekne, Latvija p.6-8.

[2] Čubars E. (2008) Lubānas ezera niedru resursu izvērtējums un to izmantošanas energijas ieguvei pamatojums/ Zinātniskais darbs magistra grāda ieguvei/ Rēzeknes Augstskola, Inženieru fakultāte. Zin.vad. Gotfrīds Noviks. Rēzekne, 70 lpp.

[3] Enerḡetisko augu audzēšana un izmantošana (2007) Adamovičs A.,Agapovs J., Aršanica A. u. c. Valsts SIA „Vides projekti”, Rīga, 43-133. lpp.

[4] Kronbergs E., Šmits M. (2009) Cutting properties of common Reed biomass. In: $8^{\text {th }}$ international scientific conference "Engineering for rural development", May 28.29., Jelgava, Latvia, p.207.

[5] Komulainen M., Simi P.,Hagelberg E., Ikonen I., Lyytinen S. (2008) Reed energy-Posibilities of using the Cammon Reed for energy generation in Southern Finland. In: Turku university of applied sciences reports 67. p.5-75.

[6] Reed up on Reed (2007) Ikkonen I., Roosaluste E., Pitkanen T.at.al. Southwest Finland regional Environment centre, Turku 2007. , p. 5-115.

[7] Kronbergs A., Kronbergs E.,Siraks E., Dalbins J. (2012) Cutting properties of arranged stalk biomass In: Proceedings of the International Scientific Conference, Renewable Energy and Energy Efficiency", p. 145.

[8] Tardenaka A., Spince B. (2006) Characterization of fuel granules and briquettes produced from fine-dispersed wastewood. In: International conference Eco-Balt 2006, Riga, Latvia, p. 37-38.

[9] LVS EN ISO 17225-1:2014:Solid biofuels- Fuel specifications and classes-Part 1: General requirements. 
[10] Arhipova I., Bāliņa S.(2006) Statistika ekonomikā. Risinājumi ar SPSS un Microsoft Excel. 2.izdevums. Rīga: Datorzinību centrs, 352. lpp.

[11] LVS CEN/TS 14775:2004: Solid biofuels- Method for the determination of ash content.

[12] Biedermann F., Obernberger I. (2005) Ash-related Problems during Biomass Combustion and Posibilities for a Sustainable Ash utilisation., p.2-3. [12.01.2016] Available: http://www.bios-bioenergy.at/uploads/media/PaperBiedermann-AshRelated-2005-10-11.pdf

[13] Kakitis A., Ancans D.,Nulle I.(2014) Evaluation of combustion properties of biomass mixtures. In: Engeniering for rural development, Jelgava, 29.-30.05.2014, p. 423-425.

[14] Jenkins B.M., Baxter L.L., Miles Jr T.R., Miles T.R.(1998) Combustion properties of biomass. In: Fuel processing Technology 54, p.22;
[15] Platače R., Adamovičs A (2014) The evaluation of ash content in grass biomass used for energy production. In:Energy Production and menegment in the 21st Century, Vol.2,p.1060.

[16] Marques G.,Rencoret J., et.all.(2010) Evaluation of the Chemical Composition of Different Non-Woody Plant Fibers Used for Pulp and Paper Manufacturing. In: The Open Agriculture Journal, 2010, pp.93-101

[17] Lizotte P., Savoie F., De Champlain A. (2015) Ash content and calorific Energy of Corn Stover Components in Eastern Canada. In: Energies 2015,8. p.4827-4838.

[18] Rancane S., Karklins A., Lazdina D., Berzins P.(2015) Biomass yield and chemical composition of perennial grasses for energy production. In: Engeniering for Rural development. Jelgava, 20.-22.05.2015., p. 550. 